Article

\title{
Life History of Oxybelus variegatus Wesmael, 1852 (Hymenoptera: Crabronidae) with a Description of the Mature Larva
}

\author{
Piotr Olszewski $^{1, *(\mathbb{D})}$, Petr Bogusch ${ }^{2}(\mathbb{D})$ and Krzysztof Szpila ${ }^{1}$ \\ 1 Department of Ecology and Biogeography, Faculty of Biological and Veterinary Sciences, \\ Nicolaus Copernicus University, Lwowska 1, 87-100 Toruń, Poland; Krzysztof.Szpila@umk.pl \\ 2 Department of Biology, Faculty of Science, University of Hradec Králové, Rokitanského 62, \\ 50003 Hradec Králové, Czech Republic; bogusch.petr@gmail.com \\ * Correspondence: thecla@wp.pl
}

check for updates

Citation: Olszewski, P.; Bogusch, P.; Szpila, K. Life History of Oxybelus variegatus Wesmael, 1852 (Hymenoptera: Crabronidae) with a Description of the Mature Larva. Insects 2021, 12, 100. https:// doi.org/10.3390/insects12020100

Academic Editor: Toshiharu Tanaka Received: 23 December 2020

Accepted: 21 January 2021

Published: 24 January 2021

Publisher's Note: MDPI stays neutral with regard to jurisdictional claims in published maps and institutional affiliations.

Copyright: (c) 2021 by the authors. Licensee MDPI, Basel, Switzerland. This article is an open access article distributed under the terms and conditions of the Creative Commons Attribution (CC BY) license (https:// creativecommons.org/licenses/by/ $4.0 /)$.
Simple Summary: Poor knowledge of the morphology of larvae and natural history data on the genus Oxybelus prompted us to research the rare digger wasp Oxybelus variegatus. We have described the mature larva for the first time and analysed the nesting behaviour of females, nest structure, prey range, phenology and accompanying kleptoparasites. Our findings indicate that this endangered species may inhabit strongly anthropogenic habitats and shows a potentially effective role in controlling dipteran crop pests such as Delia platura.

Abstract: The first comprehensive information on the bionomics of the digger wasp Oxybelus variegatus Wesmael, 1852 is presented. Females nested in small aggregations in crevices between paving stones of a frequently used pedestrian pathway in lowland agricultural wasteland. Nests were dug in the ground using mandibles, legs and abdomen. The nest consists of a main burrow with one or, rarely, two cells. The mature larva is described for the first time. The egg stage lasts for about two days before the larva hatches. The female provisioned each cell with an average of 11 paralysed male flies of Delia platura (Meigen, 1826) (Diptera: Anthomyiidae). Numerous females of dipteran kleptoparasites were observed in the nesting area of $O$. variegatus. However, only a few nests were infested by larvae of Senotainia conica (Fallen, 1810).

Keywords: bionomics; ecology; digger wasp; Oxybelus variegatus; larval morphology; kleptoparasites

\section{Introduction}

The genus Oxybelus Latreille, 1796 is widespread throughout the world, except Australia, and includes 264 species [1], of which 25 species occur in Europe [2] and 12 in Poland [3]. Oxybelus are small wasps (4-11 mm long), stockily built, often with a pattern of yellow or white spots or stripes on the abdomen. Most species prefer dry, sunny and sandy areas. Females dig the main burrow that ends with one or two cells at a depth of about 6-10 cm [4]. They prey on adult flies, mostly Anthomyiidae, Calliphoridae, Muscidae and Sarcophagidae [5]. The nest entrance remains open or is closed during provisioning of the cell, depending on the species. The paralysed prey is transported by the female, either impaled on the sting or held with middle or hind legs [4]. Species of Oxybelus also prey on species of economic and medical importance [6]. Information on the biology of Oxybelus is available in many publications, but in most cases, the data provided are scarce and general [7-10].

Mature larvae have been described for four Palaearctic species [11]: O. haemorrhoidalis Olivier, 1812 by Grandi [12]; O. argentatus Curtis, 1833 by Grandi [13]; O. lamellatus Olivier, 1811 and O. spectabilis Gerstaecker, 1867 by Asís et al. [11]. Larvae of two Holarctic species were also described: Maréchal [14,15] and Evans [16] described the larva of O. bipunctatus 
Olivier, 1812, while Evans [16] described the larva of O. uniglumis (Linnaeus, 1758). The latest publications about the behavioural ecology and biology of the genus are summarised by Andrietti et al. [17], Blösch [18], Packeman et al. [9] and Tormos et al. [19]. Information on the larval stages remains scarce and the present paper is a step towards improving this situation.

Blösch [18] reported that $O$. variegatus occurs and nests only in grey hair-grass (Corynephorus canescens L.) and among herbaceous plants on clay-sandy soil along noise barriers in Erlangen, Germany. Nicoli Aldini [20] described the nesting habits of O. variegatus in the Camonica Valley (Lombard Alps, northern Italy). The nests consisted of a burrow ending in a single cell. They remained open while females were hunting and mass provisioning with flies of the family Anthomyiidae. Grandi [12] lists three other families of prey: Muscidae, Tachinidae and Sarcophagidae. Bitsch and Leclercq [21] presented a list of plants visited by the imago of $O$. variegatus.

The objective of the present study is to provide, for the first time, a description of the mature larva of $O$. variegatus and to supplement the existing information on the nesting biology, including the (1) nesting behaviour of females, (2) male mating behaviour, (3) structure of the nest, (4) prey range, (5) phenology and (6) accompanying kleptoparasites.

\section{Materials and Methods}

The study was conducted in the town of Kowalewo Pomorskie $\left(53^{\circ} 10^{\prime} 05.7^{\prime \prime} \mathrm{N}\right.$; $18^{\circ} 52^{\prime} 15.5^{\prime \prime}$ E) in northern Poland, from early June to early August 2020 on sunny and warm days (with a temperature of at least $18^{\circ} \mathrm{C}$ ).

The study was carried out in a $26-\mathrm{m}^{2}$ backyard paved with cobblestones. It is located near a wasteland (abandoned arable land) overgrown with herbs and featuring several sandy patches. The distance between the backyard and the wasteland was about $6 \mathrm{~m}$. The dominant plant species growing in the surroundings of the study area were Tanacetum vulgare L., Taraxacum officinale F.H. Wigg., Geranium pusillum L., Trifolium arvense L., Lactuca serriola L., Cerastium holosteoides Fr. em. Hyl., Berteroa incana (L.) DC., Artemisia vulgaris L., Achillea millefolium L. and Potentilla anserina L.

The behaviour of both sexes, digging of nests and the frequency with which the female provisioned the cells were analysed on the basis of videos recorded with a Canon Camera CCD-V800E 10X and by direct observations. An additional Raynox Macroscopic Lens M-250 was also used to take photographs. The structure of the nest was analysed by removing the paving stones. The prey range was determined by nest inspections. To describe the larval specimens, we transferred some of the larvae into Pampel solution (30 volumes of distilled water, 15 volumes of $96 \%$ ethanol, 6 volumes of formaldehyde and 4 volumes of glacial acetic acid) as described by [22], while the remaining larvae were allowed to grow to the adult stage. After taking photographs of the intact larvae, we examined their sclerotised parts. For this purpose, we placed the larvae into $10 \%$ solution of hot $\left(60{ }^{\circ} \mathrm{C}\right) \mathrm{KOH}$ for $12 \mathrm{~h}$ to dilute all body parts except the integument. We then coloured the integument in 5\% Chlorazol Black E (Sigma Aldrich) for $2 \mathrm{~s}$ and then moved it into $96 \%$ ethanol. To observe the species-specific characteristics, we placed the integument into glycerol and separately observed the head, mouthparts, spiracles and other parts under a light microscope. We used the same specimens to study small structures such as setae, sensilla or mouthparts. We drew figures of (1) the head, with a focus on the clypeus, labrum, maxillae and labium; (2) mandibles-anterior view; and (3) spiracles of larvae. Specimens of kleptoparasitic flies and prey are deposited at the Department of Ecology and Biogeography of Nicolaus Copernicus University, Poland, and larvae are deposited at the University of Hradec Králové, Czech Republic. Larvae and pupae of kleptoparasitic flies and digger wasps were reared in Eppendorf tubes until they developed into imago. Breeding of digger wasps under laboratory conditions from the egg stage to pupae was not successful. 


\section{Results}

\subsection{Environmental Preferences and Nesting Behaviour}

Behavioural data. From early June to mid-July, females used gaps between paving stones to dig 32 nests (north-eastern aspect; Figure 1A-H), while from mid-July to earlyAugust, nests were also observed in adjacent areas, in the sandy area (four nests) and in the wasteland (six nests). Eight females provisioning cells with adult Diptera were observed simultaneously at the peak of the nesting period. Females were observed from 10:00 to 20:15 h, while males (Figure 2A) were most frequently flying low above the ground from 10:00 to 15:00 h ( 2 or $3 \mathrm{~cm}$ above the ground) in a twisting flight. During that time, fighting ensued when a male approached another too closely, while females were single, and copulation took place when both sexes came into contact. No copulation was observed after 15:00 h. In total, we observed three copulations lasting approximately $2 \mathrm{~min}$ on the ground.
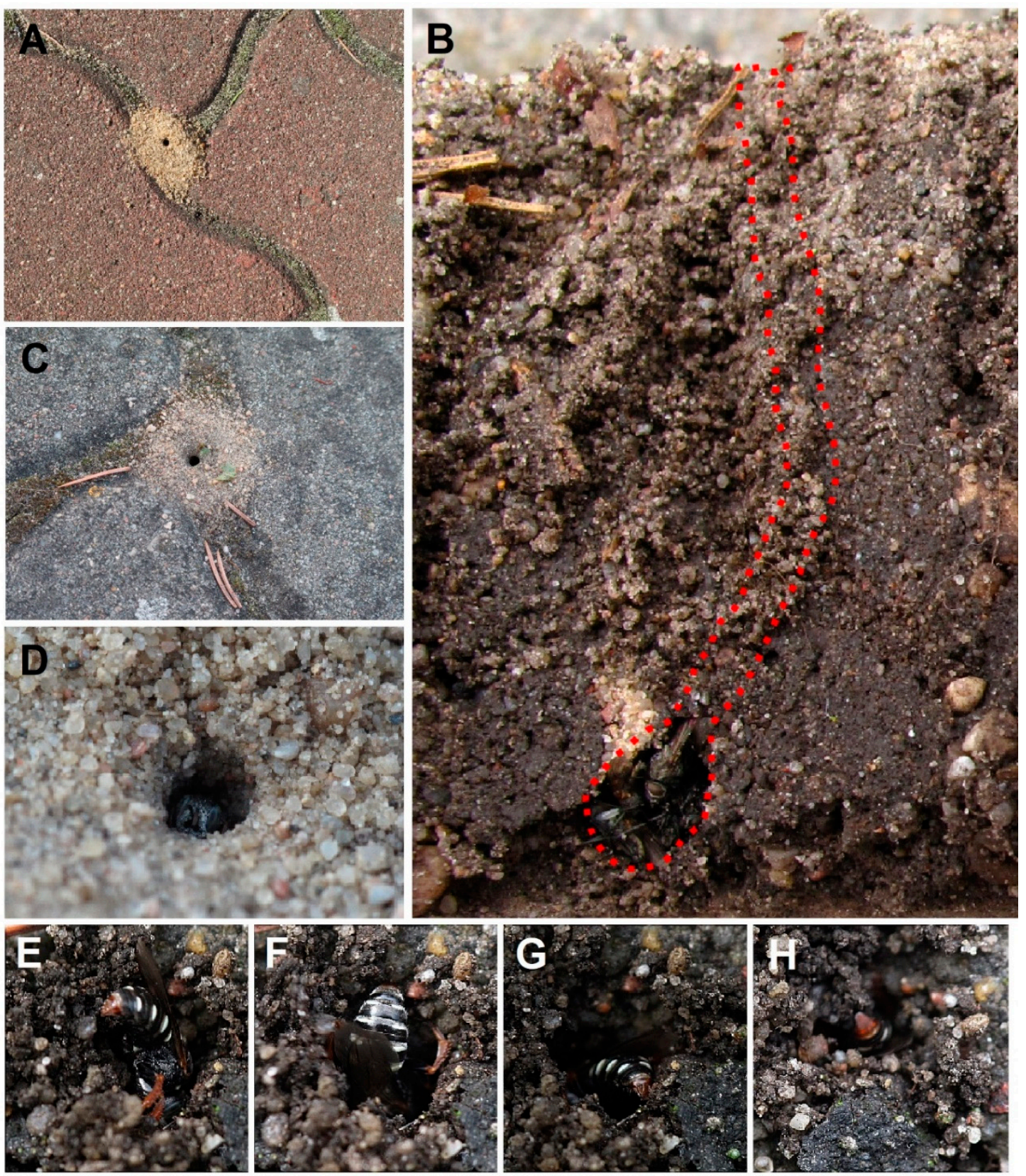

Figure 1. Nest of Oxybelus variegatus. (A,C,D) Top view of the nest entrance; (B) cross-section of the nest after removing a single paving stone; $(\mathrm{E}-\mathrm{H})$ burrow excavation. 


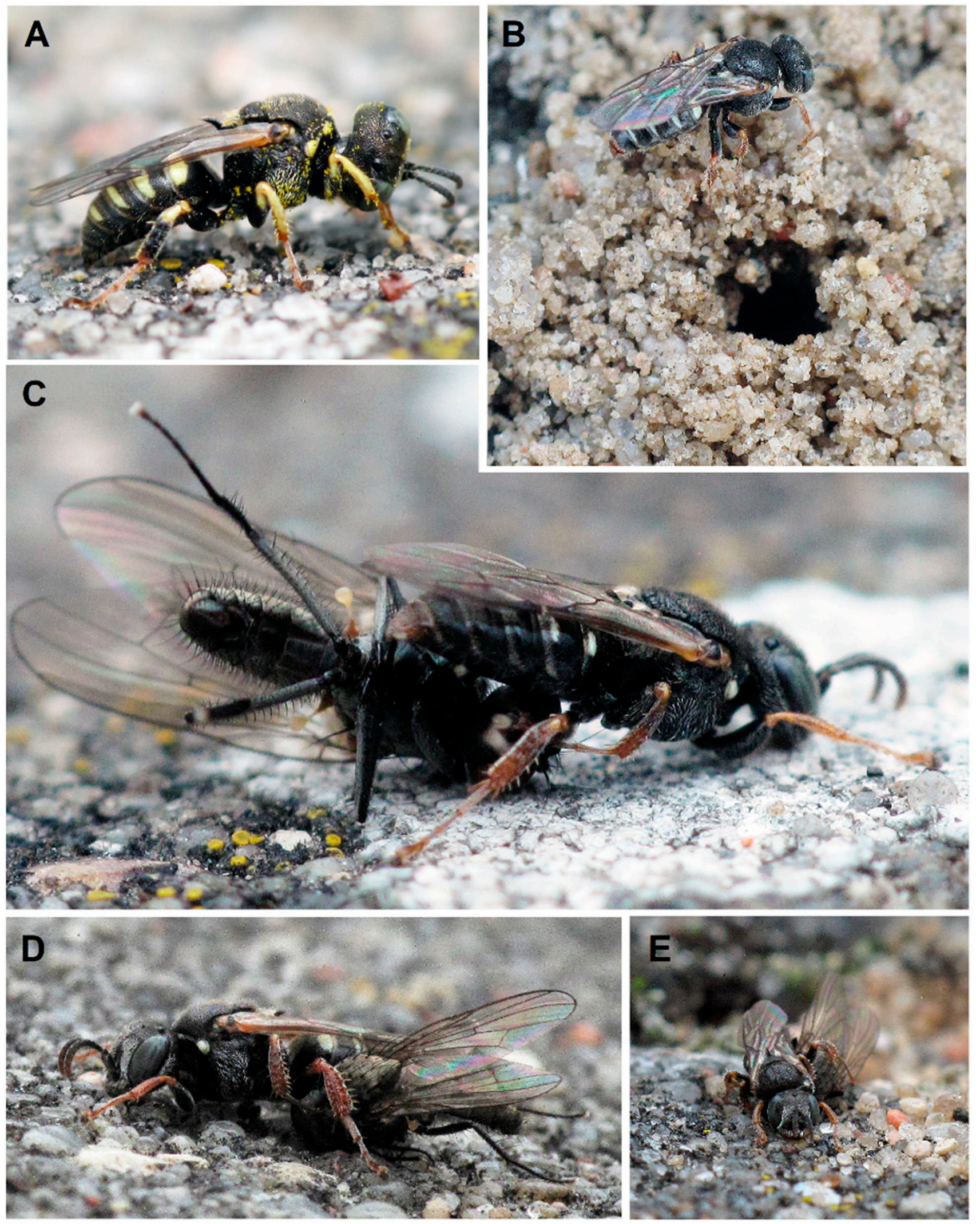

Figure 2. Adult of Oxybelus variegatus. (A) Male; (B) female in front of the nest entrance; (C-E) female with prey. 
Females (Figure 2B-E) nested in dense aggregations in summer and selected areas without vegetation to build their nests. Before selecting a nesting site, females briefly landed for test digging while flying close to the ground.

To start a nest, the female first loosened the soil crust with her mandibles and forelegs. Then, her forelegs raked the loosened soil under the raised abdomen. The female repeatedly retreated from the burrow, pushing loads of sand held between the abdominal venter and hind legs (Figure 1E-H). The excavated soil formed a small mound around the nest entrance (Figure 1A,C).

Ten nests of the colony were explored (all in the backyard area with cobblestones). The length of the main burrow was approximately $5-7 \mathrm{~cm}$, with a diameter of about 2.5-3 mm, and its course was basically vertical halfway along its length, becoming oblique afterwards and ending with a single cell $(\mathrm{N}=8)$ or, rarely, two cells $(\mathrm{N}=2)$ with a length of about $12 \mathrm{~mm}$ and a width of 5-7 $\mathrm{mm}$ (Figure 1B). On average, 11 paralysed male flies of Delia platura (Meigen, 1826) were stored in each cell (Figure 1B; Figure 3B-C). The field with beans, on which Delia platura flies probably develop, was located about $6 \mathrm{~m}$ from all breeding sites. The minimum distance between nest entrances was about $7 \mathrm{~cm}$. The entrance to the burrow was constantly open during the provisioning period. Females were observed repeatedly with their heads facing outside the entrance (Figure 1D). Females always transported their prey from the left side, impaled on their sting on the side of the thorax (Figure 2C-E), sometimes, after landing near the entrance, holding the prey close to the side using the middle legs. The provisioning female landed in front of the entrance and entered immediately. The time interval between bringing two successive prey was 2-24 min (usually 4-6 min).

The development of $\mathrm{O}$. variegatus is presented in Figure $3 \mathrm{~A}-\mathrm{H}$. A white oblong egg was laid on the ventral side of the fly and the egg placement can be classified as Crabro-style after Iwata [23] (Figure 3A). It was $1.567 \mathrm{~mm}$ long and $0.359 \mathrm{~mm}$ wide ( $=10)$. In $70 \%$ of the cases, the egg was laid on the right side of the prey. The egg stage took about two days. Breeding of the larva from the egg stage to pupa was not successful.

Kleptoparasitic flesh flies of Metopia argyrocephala (Meigen, 1824) ( $\mathrm{N}=6$; Figure 4A-B) entered the nests in the absence of the female (all observations conducted in the backyard area with cobblestones) and Senotainia conica (Fallen, 1810) ( $=7$; Figure 4C) approached the nests shortly after the female wasps returned with prey (all observations conducted on wasteland $-\mathrm{N}=2$ and sandy patches $-\mathrm{N}=5$ ). Out of all analysed nests, two larvae of $S$. conica collected in the nests from an adjacent area (sandy spot) were reared to adulthood and subsequently identified to species. More than one fly larva was not observed in the nest cell.

\subsection{Description of the Mature Larva}

\subsubsection{Material Examined}

Two specimens (Figure 5A-D).

\subsubsection{Diagnosis}

The mature larva of O. variegatus is similar to other larvae of this genus, with a fusiform body, slightly thicker body posteriorly (Figure 3E-F), conspicuous lateral tubercles and large, elongated mandibles with five teeth. It is small and resembles the larva of $O$. bipunctatus in size, from which it differs in having blunt apical teeth on the mandibles (like O. argentatus). The mature larva has many setae around the mandibular condyle. The mandible is brown and sclerotised as well as maxillary and labial palpi; the rest of the mouthparts are not pigmented. 

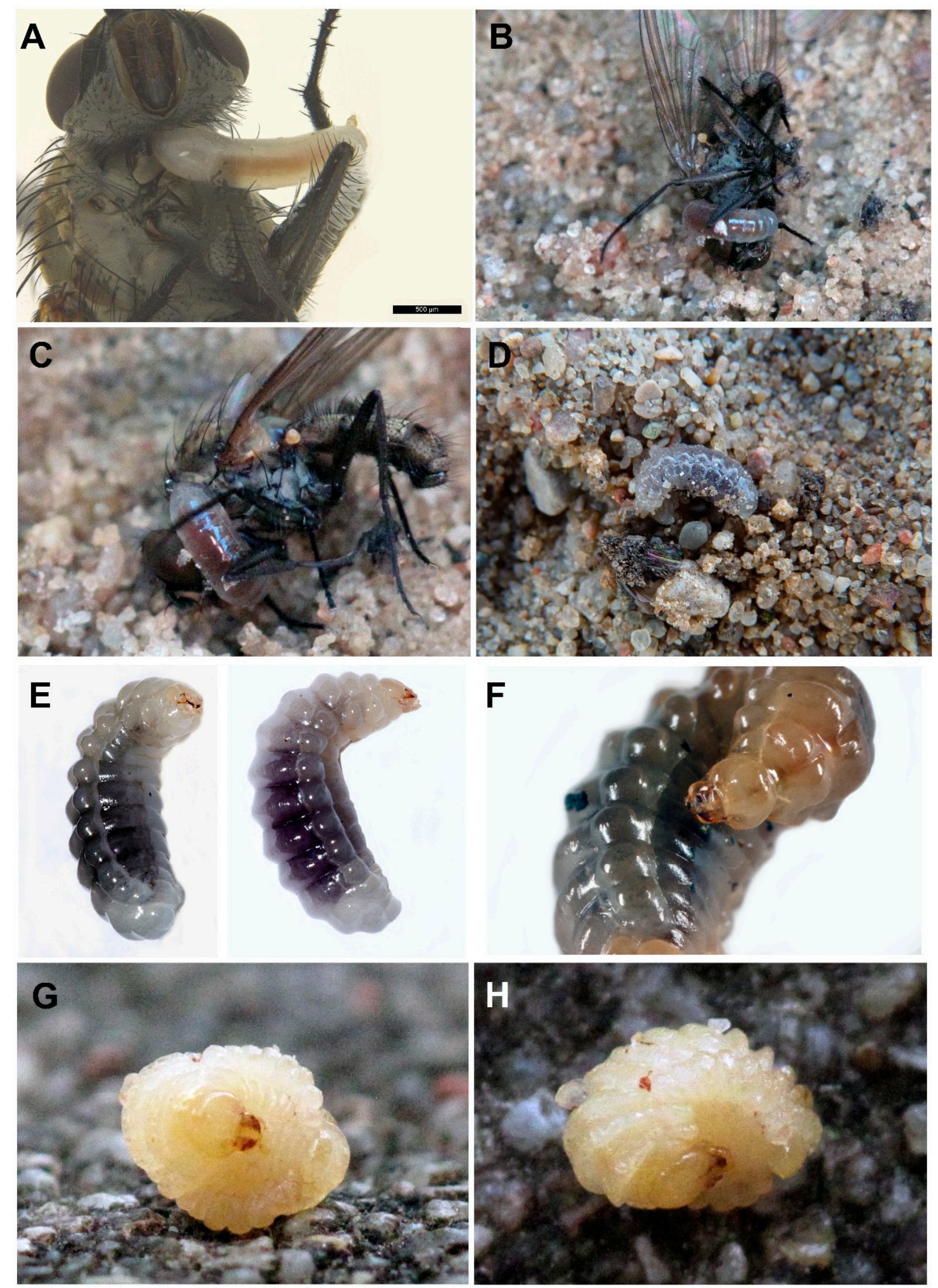

Figure 3. Developmental stages of Oxybelus variegatus. (A) Egg; (B-H) larva. 

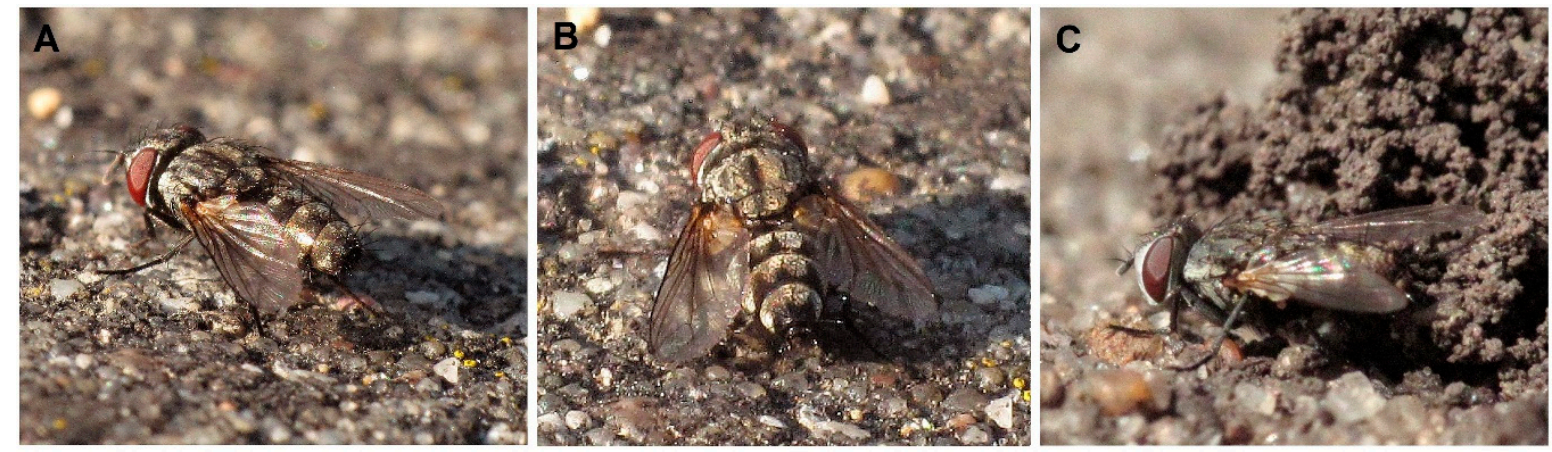

Figure 4. Kleptoparasites. (A,B) Females of Metopia argyrocephala; (C) female Senotainia conica.
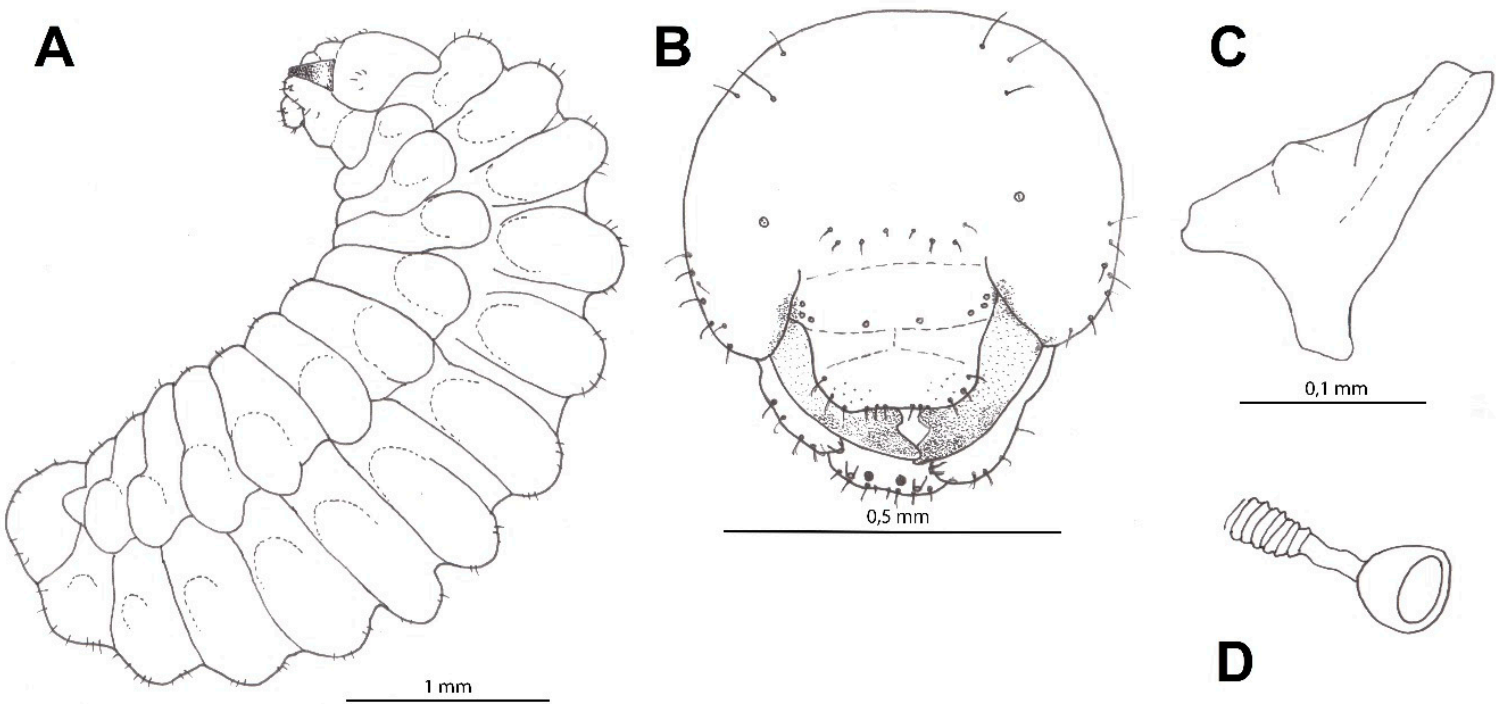

D

Figure 5. Larva of Oxybelus variegatus: (A) body, lateral view; (B) head, frontal view; (C) mandible, frontal view; (D) spiracle.

\subsubsection{Description}

Body length: 5.8-7.1 $\mathrm{mm}(\mathrm{N}=2)$. Body colour: light yellow (prepupae) or cream (larvae; Figure 3B-H). Integument with sparsely distributed short spicules and several slender, pale setae, tapering to fine points, arising from small but distinct alveoli; setae not elongated. Several setae on mouthparts; only mandible, the area around mandibular condylus as well as maxillary and labial palpi brownish. Other body parts with only a few setae, except last three metasomal segments-more setose. The body form of post-defecating larva, fusiform, robust and only slightly dorsoventrally flattened; body segments of similar width along whole length (Figure 5A). Paired body tubercles present and well developed on all mesosomal and metasomal segments except on T10; T3-T6 with most conspicuous tubercles compared to other terga, while very small on T9. Paired body tubercles on prothorax flattened and elongated, different from those on other body segments. Dorsal tubercles wide, flat and well developed on all three thoracic segments and abdominal terga, while less conspicuous on T9. Predefecating larva in side-view with first abdominal segments largest in diameter and its outline tapering slightly forwards and backwards from there. Abdominal segment 9 more hirsute than previous one, and segment 10 attached to middle of segment 9 in lateral view; anus positioned medially and transversely. Spiracles (Figure 5D) unpigmented, subequal in diameter; atrium globular, slightly wider than deep, projecting little above body wall, with rim; atrial opening diameter $0.75 \times$ peritreme width; atrial inner surface with rows of wrinkles concentric with primary tracheal opening; primary tracheal opening without collar; subatrium short, with about 10 chambers of 
approximately equal size except one or two next to atrium slightly larger in diameter. Sex characters unknown.

Head: Head is moderately small compared to whole body; oriented in normal, hypognathous position relative to the thorax. Setae are long but sparse on the upper part of head capsule; those of maxillary and labial apices are large, straight and conspicuous. Head capsule is unpigmented except at articulation with mandible; mandible is moderately pigmented except mandibular apices and articulation with head capsule conspicuously pigmented; maxillary sclerites faintly pigmented; salivary lips projecting but unpigmented; maxillary and labial palpi all uniformly moderately pigmented (Figure 5B). Coronal and postoccipital ridges absent. Tentorium mostly absent because of impending ecdysis. Parietal bands are absent. In lateral view, clypeus is roundly projecting beyond frons, antenna arising from ill-developed prominence and labrum extending beyond clypeus. Diameter of basal ring of antenna is less than $1 / 5$ of distance from the nearest point on ring to the centre of anterior tentorial pit; antennal papilla only slightly pigmented, very small and not elongated, bearing two sensilla apically. Frontal area between antennae with two linear rows of four setae. Parietal region with three setae from pleurostomal ridge to anterior tentorial pit and multiple on sides. Clypeus is wide with ill-developed basal and apical margins; two sensilla basally onside and three small sensilla more medially on each side. Labrum shallowly emarginated apicomesally, with a group of six conspicuous setae and several smaller sensilla on each side apically; labral sclerite is ill-defined and only very slightly pigmented. Epipharynx is simple with small spinulae laterally. Mandible is moderately robust, darkly pigmented, pentadentate with two blunt apical teeth and three tubercles; medial tooth with fairly sharp apex; proximal tooth blunt and well developed; outer mandibular surface is without setae (Figure 5C). Maxillary apex strongly bent mesad in frontal view, so that maxillary palpus looks subapical; cardo distinct, posterior end directed towards posterior tentorial pit; stipes sclerotised; maxillary palpus elongated, more than twice as long as its basal diameter, both pigmented. Stipes with four conspicuous setae. Labium not divided into prementum and postmentum; apex moderately narrow in frontal view. Two setae on each side and two smaller on ventral surface of labium. Salivary lips round and well visible, with inner surface bearing parallel longitudinal grooves; width of lips slightly more than twice the width of maxillary palpus. Labial palpus elongated with three sensilla in at mid-length.

\section{Discussion}

The biology of European Oxybelus Latreille, 1796 is incompletely known and the available information is mostly limited to dipteran prey for larvae, to plants as a source of nectar for adults and to environmental preferences [18,21,24-26].

Our data on $O$. variegatus on the nest structure, prey for larvae and breeding behaviour of females mostly agree with observations by Nicoli Aldini [20].

Nicoli Aldini [20] reported that the maximum number of prey in one cell was eight specimens (Anthomyiidae). In our study, this number was not less than 11 individuals per cell. The difference may depend on the species and size of captured flies.

The observations presented in this paper indicate that $O$. variegatus tolerates various types of subsoils for the construction of nests. The choice of an unusual place in crevices of paving stones to build a nest may be associated with appropriate thermal conditions (shaded area from 17:00 h) and a smaller number of kleptoparasites in this type of microhabitat. From mid-July to early August, nests were also built in the neighbouring wasteland, where at least several dozen parasitic flies were observed. Seven of them were caught and identified as $S$. conica, and two larvae of this species were subsequently found in the nests of $O$. variegatus. The low level of nest infestation by kleptoparasites is surprising in the context of the lack of temporary closure of the nest entrance by O. variegatus. This phenomenon may be related to the observed nest-guarding behaviour described also for Nearctic Oxybelus subulatus Ch. Robertson, 1889 [27]. Counter-kleptoparasitic behaviour was used by O. subulatus against flies classified as "hole searchers" and "satellites" [28], 
which corresponds well to the kleptoparasitic strategies of Miltogramminae species persecuting $O$. variegatus. In the case of $O$. variegatus, however, this nest-guarding behaviour was performed only by females and not by males, as is known for $O$. subulatus.

The upper burrow profile is vertical and similar to the nest structure of Nearctic Oxybelus [29]. This group includes $O$. sparideus, O. sericeus, O. subulatus, O. cressonii, $O$. emarginatus and O. subcornutus. Other species with described nests build the upper at an oblique angle. The nesting behaviour of $O$. variegatus is similar to that of Nearctic species [9] in the following aspects: (1) lack of temporary closure, (2) females impale the prey on their sting during transport and entry into the nest and (3) females remove sand using their abdomen during the next excavation.

Females of Oxybelus capture flies that are available and abundant near the nesting area. Some species catch only males of certain fly families $[5,17,20]$. This is consistent with our observation, where only males of Delia platura (Anthomyiidae) were the prey. The field with beans, on which Delia platura flies could develop, was located about $6 \mathrm{~m}$ from all breeding sites. It is likely that catching only male specimens was associated with their high concentration at the same time, e.g., during the swarm behaviour [30]. It is evident that the species shows some variation in the choice of prey. Gayubo and Tormos [31] list Musca domestica Linnaeus, 1758 as food for larvae, while Grandi [12], in addition to Stomoxys calcitrans (Linnaeus 1758), lists Phania curvicauda (Fallen 1820), Miltogramma brevipilum Villeneuve, 1911 and Phrosinella nasuta (Meigen, 1824), known as parasitoids or the nest parasites of other insects.

The number of European Oxybelus species with described larvae is limited [11]. However, the available data indicate morphological homogeneity of all known larvae [11-16]. This is well expressed, especially in the form of epipharynx, whose apicomedian area is smooth and without spinules [11]. The spinules are positioned mostly on the base sides, and the lacinial area is both papillose and spinulose. This characteristic is present in all known larvae of Oxybelus [11]. Within the subfamily Crabroninae, differentiates the larvae of Crabronini and Oxybelini [16]. However, this area is much smaller in O. haemorrhoidalis [11,12]. Asís et al. [11] indicate another characteristic common to all species-setae running across the ventral side of the labrum, which is also developed in O. variegatus.

Oxybelus variegatus is included on the red lists of endangered invertebrates in Poland and Germany with the status Endangered and Vulnerable, respectively [32,33]. Therefore, it is quite surprising to observe successful nesting of this species in such an anthropogenic habitat such as frequently used paving stone paths. Our observation also indicates the importance of small sandy areas in the agricultural landscape. They are used by digger wasps as nesting sites, which may have a beneficial effect on biological control of pest species $[34,35]$.

\section{Conclusions}

Females of $O$. variegatus usually dig their nests between 12:00 and 15:00 and make provisions between 15:00 and 20:15. The only prey were males of Delia platura. They transport the prey on the left side, impaled on the sting. The main burrow is almost vertical along upper half of its length, then oblique, ending with one or, rarely, two cells. The entrance to the main burrow is permanently open during provisioning. The egg is laid on the ventral side of flies and the egg placement can be classified as Crabro-style. The larva of this species is smaller in size compared to the known larvae of most species of this genus. The body shape is typical for Oxybelus larvae-fusiform, with well-developed lateral and dorsal tubercles, small spinulae on the cuticle and a relatively small head with elongated mouthparts and mandibles with three apical and two lateral teeth. Unlike most larvae of Oxybelus, the mature larva of $O$. variegatus has blunt and short apical teeth (similar to the larva of $O$. argentatus). Our research indicates that this species adapts to anthropopressure and plays a possible role in controlling dipteran crop pests such as Delia platura. 
Author Contributions: Conceptualization, P.O. and P.B.; methodology, P.O. and P.B.; formal analysis, P.O., P.B. and K.S.; data curation, P.O. and P.B.; writing-original draft preparation, P.O., P.B., K.S; writing-review and editing, P.O., P.B. and K.S.; visualization, P.O. and P.B.; funding acquisition, K.S. All authors have read and agreed to the published version of the manuscript.

Funding: K.S. was financially supported by the Polish National Science Centre (grant no. 2015/17/B/ NZ8/02453).

Institutional Review Board Statement: Not applicable.

Informed Consent Statement: Not applicable.

Data Availability Statement: The data that support the findings of this study are available from the corresponding authors, upon reasonable request.

Acknowledgments: We would like to thank Zofia and Edward Olszewski for the possibility of conducting the research and for all their help. We are very grateful to Tim Sparks (University of Cambridge) for correcting the English language, Andrzej Grzywacz (Nicolaus Copernicus University) for the identification of Delia platura (Anthomyiidae) and Jarosław Buszko (Nicolaus Copernicus University) for taking a few photos of the larva. We also thank Wojciech Pulawski (California Academy of Science), Josep Daniel Asís (University of Salamanca) and Frank Kurczewski (State University of New York) for their critical reviews of the manuscript. Fereshteh Amirmohammedi (University of Hradec Králové) helped with the descriptions of larvae.

Conflicts of Interest: The authors declare no conflict of interest. The funders had no role in the design of the study, in the collection, analyses, or interpretation of data, in the writing of the manuscript, or in the decision to publish the results.

\section{References}

1. Pulawski, W. Catalog of Sphecidae. California Academy of Sciences, San Francisco. Available online: http://research.calacademy. org/sites/research.calacademy.org/files/Departments/ent/sphecidae/Genera_and_species_pdf/Oxybe-lus.pdf (accessed on 7 May 2020).

2. Barbier, Y. Fauna Europaea: Family Crabronidae. Fauna Europea Version 1.0. Available online: http://www.faunaeur.org/full_ results.php?id=11303 (accessed on 2 November 2020).

3. Olszewski, P.; Wiśniowski, B.; Ljubomirov, T. Current list of the Polish digger wasps (Hymenoptera: Spheciformes). Spixiana 2021, manuscript in press.

4. Bohart, R.M.; Menke, A.S. Sphecid Wasps of the World. A Generic Revision; University of California Press: Berkeley, CA, USA, 1976.

5. Iwata, K. Evolution of Instinct: Comparative Ethology of Hymenoptera; Amerind Publishing Co. Pvt. Ltd.: New Delhi, India, 1976; 539p.

6. Bohart, R.M.; Schlinger, E.I. California wasps of the genus Oxybelus (Hymenoptera, Sphecidae, Crabroninae). Bull. Calif. Insect Surv. 1957, 4, 103-134.

7. Grandi, G. Studi di un Entomologo Sugli Imenotteri Superiori. Boll. Ist. Entomol. della Univ. Studi. Bologna. 1961, $25,1-661$.

8. Kazenas, V.L. Fauna and Biology of Sphecid Wasps (Hymenoptera, Sphecidae) of Kazakhstan and Central Asia; Kazgos INTI: Almaty, Kazakhstan, 2001;333p.

9. Peckham, D.J.; Kurczewski, F.E.; Peckham, D.B. Nesting behavior of Nearctic species of Oxybelus (Hymenoptera: Sphecidae). Ann. Entomol. Soc. Am. 1973, 66, 647-661. [CrossRef]

10. Tsuneki, K. Gleanings on the bionomics of the East-Asiatic non-social wasps (Hymenoptera). I. Some species of Oxybelus (Sphecidae). Etizenia 1969, 38, 1-24.

11. Asis, J.D.; Tormos, J.; Gayubo, S.F. Descripción de la larva madura de Oxybelus lamellatus Olivier y O. spectabilis Gerstaecker (Hymenoptera, Sphecidae). Misc. Zool. 1997, 20, 59-64.

12. Grandi, G. Contributi alla conoscenza biologica e morfologica degli imenotteri melliferi e predatori IX. Boll. Lab. Ent. R. Ist. Sup. Agr. Bologna. 1929, 2, 255-290.

13. Grandi, G. Contributi alla conoscenza degli imenotteri aculeati XXVI. Boll. Ist. Ent. Univ. Bologna. 1954, 20, 81-255.

14. Maréchal, P. Sur trois hyménopteres se développant dans un cocon en mosaique (Miscophus spurius Dahlb., Oxybelus bipunctatus Ol., Mutilla rufipes F.). Mém. Soc. Entomol. Belg. 1930, 23, 1-23.

15. Maréchal, P. Sur trois hyménopteres se développant dans un cocon en mosaique (supplément). Mém. Soc. Entomol. Belg. 1930, 23, 163.

16. Evans, H.E. Studies on the larvae of digger wasps (Hymenoptera, Sphecidae). Part III: Philanthinae, Trypoxyloninae, and Crabroninae. Trans. Amer. Ent. Soc. 1957, 83, 79-117.

17. Andrietti, F.; Polidori, C.; Casiraghi, M.; Bellati, A.; Passerini, E.; Martinoli, A. Small-scale sympatric digger wasps Oxybelus argentatus and Oxybelus trispinosus segregate activity, hunt for different prey, and diverge in nesting behavior. Ann. Soc. Entomol. Fr. Nouv. Série 2013, 49, 205-221. [CrossRef] 
18. Blösch, M. Die Grabwespen Deutschlands. Sphecidae s. str., Crabronidae. Lebensweise, Verhalten, Verbreitung. In Die Tierwelt Deutschlands. 71. Teil; Blank, S.M., Taeger, A., Eds.; Goecke \& Evers: Keltern, Germany, 2000; 480p.

19. Tormos, J.; Asís, J.D.; Gayubo, S.F.; Portillo, M.; Torres, F. Nesting behavior of Oxybelus lamellatus Olivier (Hymenoptera: Sphecidae). Ann. Entomol. Soc. Am. 2000, 93, 326-332. [CrossRef]

20. Nicoli Aldini, R. Behavioural observations on three species of Oxybelus (Hymenoptera Sphecidae) nesting in syntopy. Redia 2004, LXXXVII, 253-256.

21. Bitsch, J.; Leclercq, J. Hyménoptères Sphecidae d'Europe occidentale. 1. Faune de France. 79; Fédération Française des Sociétés de Sciences Naturelles: Paris, France, 1993; 325p.

22. Švácha, P.; Danilevsky, M.L. Cerambycoid larvae of Europe and Soviet Union. Part I. Acta Univ. Carol. Biol. 1987, $30,1-176$.

23. Iwata, K. Comparative studies on the habits of solitary wasps. Tenthredo Acta Entomol. 1942, 4, 1-142.

24. Berland, L. Hyménoptères vespiformes, I, Sphegidae, Pompilidae, Scoliidae, Sapygidae, Mutillidae; Paul Lechevalier: Paris, France, 1925; Volume 10, 364p.

25. Guiglia, D. Gli Oxybelini d'Italia. Ann. Mus. Civ. Storia Nat. Genova 1953, 66, 55-158.

26. Mingo Perez, E. Los Oxybelini de la penisula iberica (Hymenoptera). Graellsia 1966, XXII, 57-121.

27. Spofford, M.G.; Kurczewski, F.E. Counter-cleptoparasitic behaviours of species of Sphecidae (Hymenoptera) in response to Miltogrammini larviposition (Diptera, Sarcophagidae). J. Nat. Hist. 1992, 26, 993-1012. [CrossRef]

28. Spofford, M.G.; Kurczewski, F.E. Comparative larvipositional behaviours and cleptoparasitic frequencies of Nearctic species of Miltogrammini (Diptera: Sarcophagidae). J. Nat. Hist. 1990, 24, 731-755. [CrossRef]

29. Peckham, D.J.; Hook, A.W. Behavioral observations on Oxybelus in southeastern North America. Ann. Entomol. Soc. Am. 1980, 73, 557-567. [CrossRef]

30. Ellis, S.; Scatcherd, J. Bean seed fly (Delia platura, Delia florilega) and onion fly (Delia antiqua) incidence in England and an evaluation of chemical and biological control options. Tests Agrochem. Cultiv. 2007, 151, 259-267. [CrossRef]

31. Gayubo, S.F.; Tormos, J. Nuevas Aportaciones al Conocimiento de la Esfecidofauna Valenciana (II) (Hym., Sphecidae); Serie Hymenoptera, Cuaderno 2; Publica Fun da ción Entomológica "Juan de Torres Sala": Valencia, Spain, 1986; 35p.

32. Skibińska, E. Sphecidae Grzebaczowate. In Red List of Threatened Animals in Poland; Głowaciński, Z., Ed.; Instytut Ochrony Przyrody PAN: Kraków, Poland, 2002; pp. 66-68.

33. Schmid-Egger, C. Rote Liste der Wespen Deutschlands. Hymenoptera Aculeata: Grabwespen (Ampulicidae, Crabronidae, Sphecidae), Wegwespen (Pompilidae), Goldwespen (Chrydididae), Faltenwespen (Vespidae), Spinnenameisen (Mutillidae), Dolchwespen (Scoliidae), Rollwespen (Tiphiidae) und Keulhornwespen (Sapygidae). Ampulex 2010, 1, 5-39.

34. Heneberg, P.; Bogusch, P.; Řezáč, M. Roadside verges can support spontaneous establishment of steppe-like habitats hosting diverse assemblages of bees and wasps (Hymenoptera: Aculeata) in an intensively cultivated central European landscape. Biodivers. Conserv. 2017, 26, 843-864. [CrossRef]

35. Heneberg, P.; Bogusch, P.; Řezáč, M. Numerous drift sand "specialists" among bees and wasps (Hymenoptera: Aculeata) nest in wetlands that spontaneously form de novo in arable fields. Ecol. Eng. 2018, 117, 133-139. [CrossRef] 